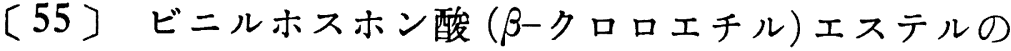 \\ $\gamma$ 線塊状重合
}

(1965 年 10 月 14日受理)

藤井茂忠* ・山北尋 巳*・松田龍夫*

\begin{abstract}
要 旨 $\quad+40 \sim-78^{\circ} \mathrm{C}$ の温度範囲におけるビニルホスホン酸 $(\beta$-クロロエチル) エステルの $\gamma$ 線塊状 重合について検討した。モノマーが液相，固相のいずれにおいても反応はラジカル機構で進み，見かけの活性 化エネルギーはそれぞれ 2.4 , および $2.2 \mathrm{kcal} / \mathrm{mol}$ で類似するが, 頻度係数は相違した。ラジカル生成の $G$ 值はかなり大きい。重合速度 $\left(R_{p}\right)$, および生成ポリマーの数平均分子量 $\left(\bar{M}_{n}\right)$ と線量率 $(I)$ との関係につ、 $\tau, R_{p} \propto I^{0.8}$ と $\bar{M}_{n} \infty I^{-0.22}$ の関係が得られ，また， $\bar{M}_{n}$ は著しく小さい。これらの結果を degradative chain transfer の機構で考察した。
\end{abstract}

\section{1. 緒言}

ビニルホスホン酸, およびその誘導体の重合に関する 従来の研究は少ない。共重合の研究が, ジメチル 1-プ ロペン 2-ホスホネート1)，1-フェニルビニルホスホン 酸)，およびビニルホスホン酸ジェチルエステル2) と，メ タクリル酸メチル，アクリロニトリル，およびスチレン などとの組合せについて行なわれ，ビニルホスホン酸系 化合物は，いずれも反応性比の小さいことが認められて いる。また, 単独重合については, ジェチルェステルや ジイソプロピルェステルなどのラジカル触媒による重合 では, 液状の低重合度の重合体しか得られないが3),4), ジ エチルェステルについてはナフタリンナトリウムによる アニオン重合によって固体の重合体が得られている4。

ビニルホスホン酸 ( $\beta$-クロロエチル) エステル（以下 CEVP と略記する), の重合についても過酸化ベンゾイ ル触媒によっては低重合度の重合体しか得られていない し, 共重合の反応性比は小さい(5)。本研究では CEVP について固相から液相にわたる広い温度範囲での $\gamma$ 線 重合を行なった。イオン重合の可能性は得られず, ラジ カル重合ではあったが，通常のビニルモノマーの重合と は異なった結果が得られ，その重合機構を考察した。

\section{2. 実験方法}

\section{1 モノマーの合成}

Gefter らの方法 ${ }^{6)}$ を改良した山下らの方法"5゙にり， 次の 3 段階を経て合成した。

1) $\mathrm{PCl}_{3}+3 \mathrm{CH}_{2}-\mathrm{CH}_{2} \stackrel{10 \sim 25^{\circ} \mathrm{C}}{\longrightarrow} \mathrm{P}\left(\mathrm{OCH}_{2} \mathrm{CH}_{2} \mathrm{Cl}\right)_{3}$

2) $\mathrm{P}\left(\mathrm{OCH}_{2} \mathrm{CH}_{2} \mathrm{Cl}\right)_{8}$ 整異性化<smiles>O=[PH](CCC(Cl)(Cl)Cl)OCCCl</smiles>

* 工業技術院名古屋工菜技術試検所 (名古屋市北区平手町 1)
3)

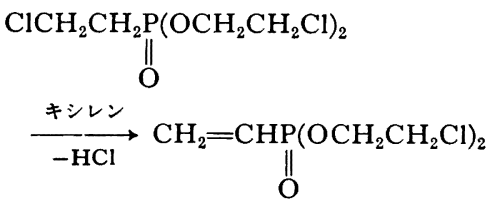

CEVP は無色無臭, 比較的重い液体で $\left(d^{20}=1.321\right)$ アルコール，エーテル，ベンゼンに可溶である。 $-40^{\circ} \mathrm{C}$ 付近に軟化点を有する。重合に用いた試料は 5 6 回減 圧蒸留 $\left(122 \sim 124^{\circ} \mathrm{C} / 2 \mathrm{mmHg}\right)$ して精製した。IR スペ クトルは $1620 \mathrm{~cm}^{-1} に$ 典型的なビニル基の吸収と, $1045 \mathrm{~cm}^{-1}$ に $\mathrm{P}-\mathrm{O}-\mathrm{C}$ による広い吸収を有する。

\section{2 重 合}

モノマーを $10^{-5} \mathrm{mmHg}$ の真空下でアンプルに封入 し, ${ }^{60} \mathrm{Co}-\gamma$ 線照射を行なった。重合速度測定にはディ ラトメーター法も併用した。照射した試料はただちに開 管し，多量のエチルェーテル中に投じてポリマーを沈殿 させ, 遠心分離した後, 真空乾燥した。分子量測定には 塩化メチレンを溶媒に, ェチルェーテルを沈殿剤にして 再沈殿をくり返したものを試料とした。

\section{3 ラジカル生成の $\boldsymbol{G}$ 值の測定}

モノマーラジカル生成の $G$ 值は $\mathrm{DPPH}$ 法により求 めた。モノマー中に $1 \times 10^{-2} \mathrm{~mol} / l$ 程度の $\mathrm{DPPH}$ を溶 解させ，真空封管して $\gamma$ 線照射を行なった。照射後開 管してジオキサンで希釈したものを日立自記分光光度計 EPS-2 型を用いて $520 \mathrm{~m} \mu$ における吸収強度を測定し た。使用した DPPH は常法により精製したものである。 モノマー中に DPPH を溶解させると, 徐々にこれを消 費するため，照射試料と同じ条件においた未照射試料を 標準として吸収強度を測定した。

\section{4 ポリマーの諸性質の测定}

得られたポリマーは各種溶媒に対する溶解性, IR ス ペクトル,分子量などを測定した。IR スペクトルはポリ マーのアセトン溶液を岩塩板上に塗布して, 減圧乾燥し た試料を用いた。分子量の測定には Mechrolab 社製, 
301-A 型 Vapour pressure osmometer を使用した。 試料は濃度約 $35 \mathrm{~g} / 100 \mathrm{cc}$ のテトラハイドロフラン溶液 を作り, $37^{\circ} \mathrm{C}$ で測定した。標準物質には Merck 社製, GR のジフェニールをそのまま使用した。

\section{3. 実験結果}

\section{1 予備実験}

水および酸素の存在は重合速度を低下させる。特に水 の影響は著しく, $0.2 \%$ の水の存在によって重合速度は 約 $1 / 2$ に低下する。また, 酸素の影響については, $1 \times$ $10^{-5} \mathrm{mmHg}$ 以下で封管したときの重合率 $43 \%$ が, $5 \times$ $10^{-1} \mathrm{mmHg}$ のときは $15.3 \%$ に低下する。したがって, データの再現性を期するため, モノマーの封管時の水の 吸収および脱気には特に注意した。なお，酸素によって 重合が抑制されることは, 後記のラジカル重合禁止剤添 加の結果ともあわせて, 重合反応がラジカル機構で進む ことを支持する。

\section{2 線量率の影響}

照射時間-重合率曲線を Fig. 1 亿, 初期重合速度一線 量率の関倸を Fig. 2 に示した。重合には若干の誘導期 を有するが, 重合速度は線量率の約 0.8 乗に比例した。

重合率と数平均分子量 $\bar{M}_{n}$ との関倸を Fig. 3 に示 す。線量率の低いときには $\bar{M}_{n}$ は重合の進行とともに 減少する傾向があるが，一般には重合の進行とともに $\bar{M}_{n}$ は増加する。重合率 0 に外插して求めた $\bar{M}_{n}$ と線量 率との関倸を Fig. 2 に併記した。これより $\bar{M}_{n} \propto I^{-0.22}$ の関倸が得られた。

\section{3 重合温度の影響}

モノマーが液相，および固相のときの照射時間-重合 率曲線を Fig. 4 に示す。重合温度の高いほど初期重合 速度は大きく, また, 重合の進行とともに重合速度の増 加する傾向があって，この現象は特に温度の低いときほ ど低重合率で現われた。これはポリマーの生成によって

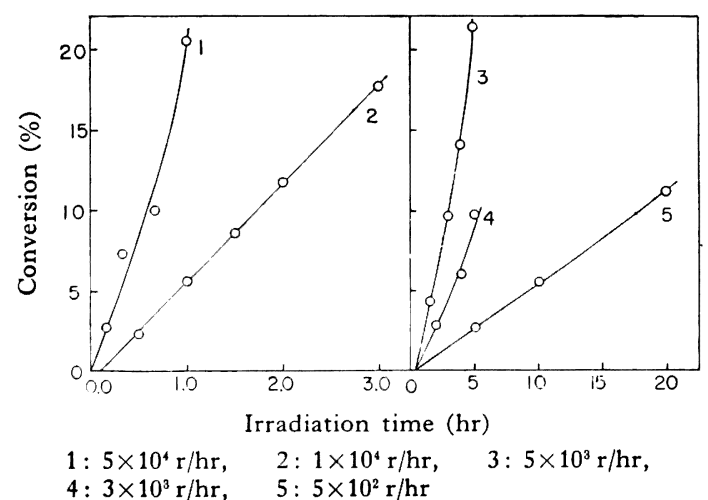

Fig. 1. Effect of dose rate on the bulk polymerization of $\beta$-chloroethyl vinylphosphonate at $40^{\circ} \mathrm{C}$.

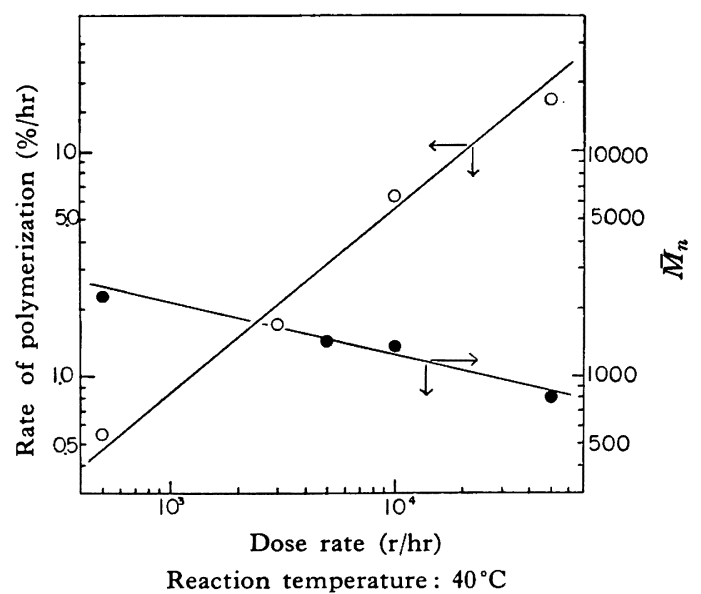

Fig. 2. Relationships between the rate of polymerization or the number average molecular weight and the dose rate.

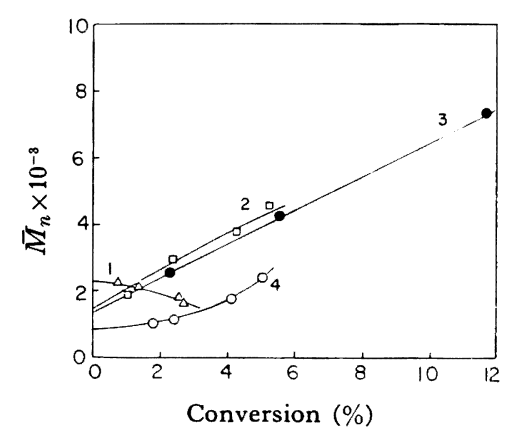

1: $5 \times 10^{2} \mathrm{r} / \mathrm{hr}, \quad 2: 5 \times 10^{3} \mathrm{r} / \mathrm{hr}, \quad 3: 1 \times 10^{4} \mathrm{r} / \mathrm{hr}$, 4: $5 \times 10^{4} \mathrm{r} / \mathrm{hr}$

Fig. 3. Effect of dose rate on the molecular weight of the polymer formed in the polymerization at $40^{\circ} \mathrm{C}$.

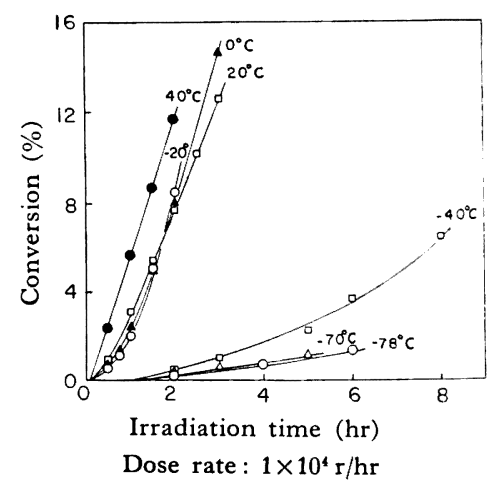

Fig. 4. Effect of irradiation temperature on the bulk polymerization. 
系の粘度が増加し、いわゆる「ゲル効果」に起因するも のと思う。Fig. 4 の結果を Arrhenius プロットした Fig. 5 より, 見かけの活性化ェネルギーは液相において は $2.4 \mathrm{kcal} / \mathrm{mol}$, 固相では $2.2 \mathrm{kcal} / \mathrm{mol}$ と計算された。 Fig. 5 について液相と固相のときの断層は, 頻度俰数に 起因するもので, 同じような現象がステアリン酸ビニル について認められている。すなわち, 融点の上と下とで は重合速度が異なるが, Arrhenius プロットにおける直 線の勾配はほぼ同じとなる7。

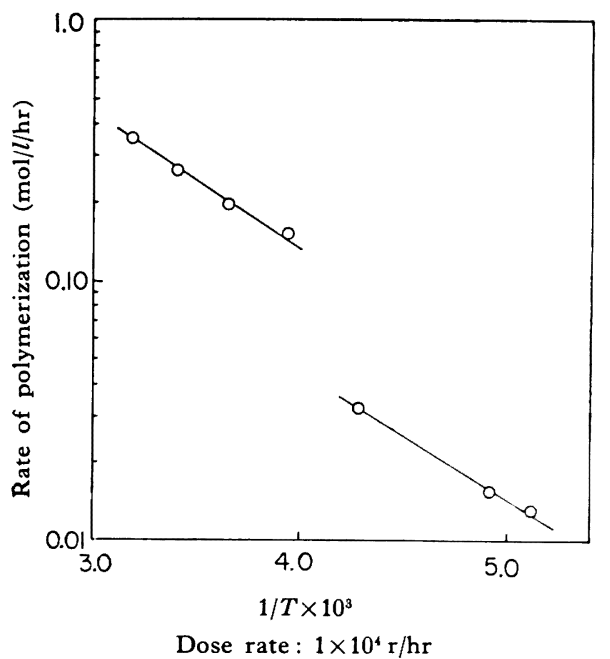

Fig. 5. Rate of polymerization as a function of reciprocal of absolute temperature.

\section{4 ラジカル重合禁止剂の影響}

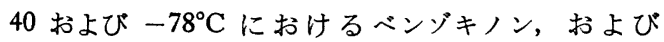
DPPH の添加の効果を Fig. 6 に示す。 $0.03 \mathrm{~mol} \%$ のべ

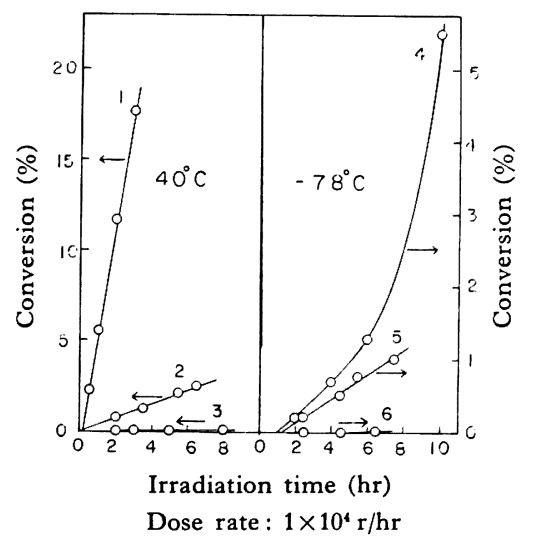

$1,4:$ no inhibitors, $2,5: 0.03 \%$ benzoquinone $3,6: 0.03 \% \mathrm{DPPH}$

Fig. 6. Influence of radical scavengers on the polymerization.
ンゾキノンの添加によって重合が抑制されるが, $-78^{\circ} \mathrm{C}$

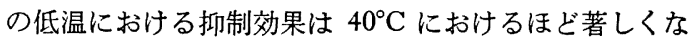
い。 $-78^{\circ} \mathrm{C}$ では系が固相のため, ベンゾキノンの拡散 が悪いためであろ5。一方, DPPH の添加によっては, いずれの温度のときにも重合は完全に禁止された。

モノマーラジカル生成の $G$ 值を求めるための DPPH の濃度変化を照射時間に対しプロットしたものが Fig. 7 である。これより $\mathrm{DPPH}$ の消費速度を求めると, 1.67 $\times 10^{-7} \mathrm{~mol} / l \cdot \mathrm{sec}$ となり, DPPH 1 分子が 1 個のラジカ ルを捕捉すると仮定して, ラジカル生成の $G$ 值を求め ると，47.1 となる。これは他のビニルモノマーに比べ てかなり大きな值であり, 重合速度の大きいのは扑に これに起因するものであろう。

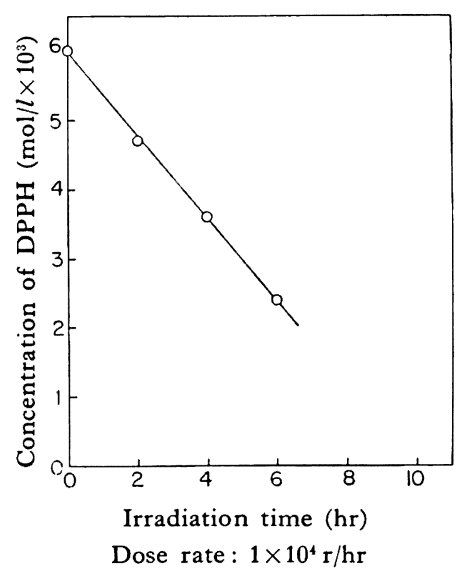

Fig. 7. Decay of DPPH in $\beta$-chloroethyl vinylphosphonate by gamma-ray irradiation at $40^{\circ} \mathrm{C}$.

\section{5 ポリマーの性質}

得られる重合初期のポリマーは無色透明で, 粘稠な糊 状のものであり, 有機溶媒に比較的良く溶解する。この ものはアルコール, ケトン類, 塩素化炭化水素などに可 溶で, 芳香族系炭化水素, エーテルなどには不溶である。 したがって, 熱重合により得られるポリマーと溶解性に ついて大差はないが，放射線重合でゲル化を起こしたも のは上記の可溶な溶媒に詨し膨潤をするが, もはや溶解 しなくなる。

液相重合の場合も固相重合の場合も, ポリマーの IR スペクトルは, 過酸化ベンゾイル触媒で得られたポリ マーのスペクトルと全く同じで, モノマーで見られた $1620 \mathrm{~cm}^{-1}$ のビニル基の吸収が消滅した。

\section{4. 考察}

モノマーが液相, および固相のいずれの重合のときに も, 重合は酸素やラジカル重合禁止剤によって抑制, ま 
たは禁止することおよび生成ポリマーの IR スペクト ルが過酸化ベンゾイル触媒を用いて得られたポリマーの それと同じで, ビニル基の吸収が消滅することなどから， 液相と固相のいずれの重合反応もモノマーのビニル基で 起こるラジカル機構で進むことが結論できる。

常温付近での重合は均一采反応であるが，重合速度掞 よび生成ポリマーの分子量と線量率との間に, 次の関係 が得られた。

$$
R_{p} \propto I^{0.8}, \quad \bar{M}_{n} \propto I^{-0.22}
$$

典型的なラジカル重合反応について，2 分子停止反応の ときには $R_{p} \propto I^{0.5}, \bar{M}_{n} \propto I^{-0.5}$ の関倸に, 1 分子停止反 応のときには $R_{p} \propto I, \bar{M}_{n} \propto I^{0}$ の関係になるので, 本実 験の上記の指数から CEVP の重合は 2 分子停止反応の 外に 1 分子停止反応が活発に起こっていることが推定さ れる。

また, DPPH 法で求めたモノマーのラジカル生成の $G$ 值はかなり大きいが, 生成ポリマーの $\bar{M}_{n}$ は数千程 度であって, 通常のビニルモノマーのものにくらべると 著しく小さい特徴がある。低重合度のポリマーの生成機 構として，1）停止反応に 1 次生成ラジカル相互または, 1 次生成ラジカルと鎖状ラジカルとの反応，2）モノマー への連鎖移動反応，の二つの場合が考えられる。1)の 場合は一般に線量率が著しく大きいときに認められてい るが，このときの重合速度の線量率に 対する依存性は, 0.5 乗より 0 乗に近づく值になって本実験結果に反す る。一方, 低重合度のポリマーの生成は本実験の CEVP ばかりでなく, 他のビニルホスホン酸系モノマーについ てラジカル触媒重合のときにも共通して起こるもので, この基因として連鎖移動反応が挙げられている ${ }^{2), 3) 。 し ~}$ たがって, 本実験の場合にも放射線照射の特異な重合条 件に由来するものではなくて，鎖状ラジカルとモノマー またはポリマーとの連鎖移動反応が活発なことによるた めであろう。

生成したラジカルは $\mathrm{CH}=\mathrm{P}=\mathrm{O}$ 型の共鳴で安定化さ れて, さらに，モノマーを付加する能力を失う。すなわ ち, 低重合度のポリマーの生成は活発な “ degradative chain transfer” の反応によるものと推定され，また，停 止反応がこの反応のみのときには $R_{p} \infty I$ の関倸が成り 立つ。このような例は $\alpha$-メチルスチレンの放射線重合 について報告されている ${ }^{8)}$ 。結局, 本実験の $R_{p}$ または $\bar{M}_{n}$ と $I$ との関倸についても, 停止反応にラジカル相互 間の 2 分子停止反応とともに, 1 分子停止反応の “degradative chain transfer”を考えることによって説明 できる。

以上の考察から重合の素過程を次のように考える。

$$
\text { 開始反応 } \quad \mathrm{M} \stackrel{\phi I}{\longrightarrow} \mathrm{R} \text {. }
$$

生長反応 $\quad \mathrm{RM}_{n} \cdot+\mathrm{M} \stackrel{k_{p}}{\longrightarrow} \mathrm{RM}_{n+1}$.

モノマーへの連鎖移動

$$
\mathrm{RM}_{n} \cdot+\mathrm{M} \stackrel{k_{t r, m}}{\longrightarrow} \mathrm{RM}_{n}+\mathrm{M} \cdot
$$

Degradative chain transfer

$$
\mathrm{RM}_{n} \cdot+\mathrm{M} \stackrel{k_{t r, d}}{\longrightarrow} \mathrm{RM}_{n}+\mathrm{X} \cdot
$$

停止反応

$$
\mathrm{R}_{m} \cdot+\mathrm{R}_{n} \cdot \stackrel{k_{t}}{\longrightarrow} \mathrm{RM}_{m+n} \text { (or } \mathrm{RM}_{m}+\mathrm{RM}_{n} \text { ) }
$$

定常状態を仮定すると，

$$
\begin{aligned}
\frac{1}{\bar{P}_{n}} & =\frac{k_{t r, m}\left[\mathrm{RM}_{n} \cdot\right][\mathrm{M}]+k_{t r, d}\left[\mathrm{RM}_{n} \cdot\right][\mathrm{M}]+k_{t}\left[\mathrm{RM}_{n} \cdot\right]^{2}}{k_{p}\left[\mathrm{RM}_{n} \cdot\right][\mathrm{M}]} \\
& =\frac{k_{t r, m}+k_{t r, d}}{k_{p}}+\frac{k_{t}\left[\mathrm{RM}_{n} \cdot\right]}{k_{p}[\mathrm{M}]} \\
& =\frac{k_{t r, m}+k_{t r, d}}{k_{p}}+\frac{k_{t}}{k_{p}{ }^{2}[\mathrm{M}]^{2}} R_{p}
\end{aligned}
$$

本実験結果より $1 / \bar{P}_{n} \propto R_{p}$ の関倸は Fig. 8 に示すよ らに直線関係になって次式が得られた。

$$
\frac{1}{\bar{P}_{n}}=0.106+7.4 \times 10^{2} R_{p}
$$

上式から，モノマーへの連鎖移動が関与する項は 0.106 になり,この值は連鎖移動反応の活発だと言われている 酢酸ビニルの光重合 $\left(25^{\circ} \mathrm{C}\right)^{9)}$ のときの $C_{M}=2.5 \times 10^{-4}$ にくらべると約 400 倍も大きな值である。また, 直線の

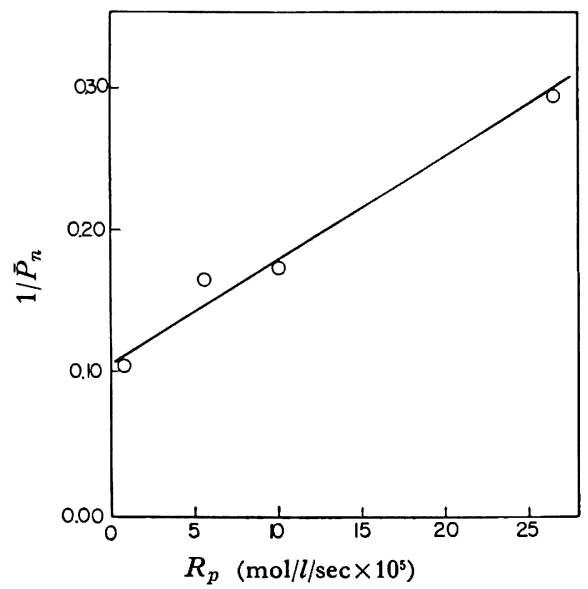

Fig. 8. Relationship between the reciprocal of average degree of polymerization $\left(\bar{P}_{n}\right)$ and the rate of polymerization at $40^{\circ} \mathrm{C}$. 
傾斜は $7.4 \times 10^{2}$ となり, $40^{\circ} \mathrm{C}$ における $[\mathrm{M}]=5.56 \mathrm{~mol} / \mathrm{l}$ (モノマーの比重: $\left.d_{*}^{* 0}=1.3055\right)$ より, $k_{t} / k_{p}{ }^{2}=24.0$ の 值が得られた。これは酶酸ビニルの $31.5\left(30^{\circ} \mathrm{C}\right)$ と同程 度の大きさである(10)。

付 記: この研究の一部は高分子学会東海支部大会 (1962 年 11月)において報告した。なお，本実験にあたり種々御便宜を いただた名大工学部, 山下维也教授に深謝いたします。

$$
\text { 文献 }
$$

1) C. S. Marvel, J. C. Wright: J. Polymer Sci., 8, 255(1952)

2) C. L. Arcus, J.R.S. Matthews : J. Chem. Soc., 4607(1956)
3) R. M. Pike, R. A. Cohen : J. Polymer Sci., 44, 531 (1960)

4）津田鉄雄, 山下雄也：工化，65，811(1962)

5）山下雄也：私信

6) E. L. Gefter, P. M. Moshkin: C.A, 54, 24345 (1960)

7) W. Burlant, A. Adicoff: J. Polymer Sci., 27, 269(1958)

8) K. Hirota, K. Makino, K. Kuwata, G. Meshitsuka : Bull. Chem. Soc. Japan, 33, 251 (1960)

9) H. Kwart, H. S. Broadbent, P. D. Bartlett : J. Am. Chem. Soc., 72, 1060 (1950)

10) 岡村誠三, 大石良季, 稲垣 寛: 京大化繊研講, 14, 103(1957)

\title{
Radiation Induced Polymerization of $\beta$-Chloroethyl Vinylphosphonate
}

\author{
By Shigetada Fujii*, Hiromi Yamakita* and Tatsuo Matsuda*
}

The gamma-ray induced bulk polymerization of $\beta$-chloroethyl vinylphosphonate was studied within the range from $-78^{\circ} \mathrm{C}$ to $40^{\circ} \mathrm{C}$. The polymerization both in the liquid and the solid phases proceeded by a free radical mechanism, and the activation energy in the liquid phase was similar to that in the solid phase with the different frequency coefficients. These were 2.4 and $2.2 \mathrm{kcal} /$ mol, respectively. The $G$-value of free radical formation was observed to be considerably large. The relationships between the rate of polymerization $\left(R_{p}\right)$ or the molecular weight of the polymer $\left(\bar{M}_{n}\right)$ and the dose rate $(I)$ were found to be $R_{p} \propto I^{0.8}$ and $\bar{M}_{n} \propto I^{-0.22}$, though $\bar{M}_{n}$ was extremely small. These results were discussed in connection with a degradative chain transfer mechanism.

* Government Industrial Research Institute, Nagoya (1-Chome, Hirate-machi, Kita-ku, Nagoya) 